\title{
The Taxonomy of the Crown-gall Organism Agrobaterium tumefaciens and Its Relationship to Rhizobia and Other Agrobacteria
}

\author{
By L. O. WHITE* \\ Department of Bacteriology, University of Birmingham, Birmingham, BI5 $2 T J$
}

(Received I4 January 1972; revised I5 May 1972)

SUMMARY

Strains of agrobacteria, rhizobia and other organisms were collected from various sources and tested for their ability to utilize 6I compounds as sole carbon sources, oxidative or fermentative glucose metabolism, hydrolysis of starch, casein and gelatin, anaerobic arginine metabolism and production of 3-ketolactose. The resulting data was used in a numerical analysis and the strains were grouped on the basis of overall similarity.

The resultant groupings confirmed the idea that the genera Agrobacterium and Rhizobium be combined, and four species of fast-growing rhizobia were recognized: Group I, Rhizobium radiobacter; Group II, Rhizobium meliloti; Group III, related to Agrobacterium rhizogenes and the Biotype 2 strains of Keane, Kerr \& New (1970); Group IV, Rhizobium leguminosarum. Crown-gall organisms were associated with groups I and III. The four species were defined without reference to pathogenicity or nodulating ability and it appears at present that crown-gall organisms can only be distinguished by pathogenicity testing.

Agrobacterium rubi $\mathbf{H} 36$ probably belongs in the genus Rhizobium whereas Agrobacterium gypsophilae 1948 and Agrobacterium pseudotsugae 180 do not.

\section{INTRODUCTION}

The crown-gall organism, called Bacterium tumefaciens by its discoverers, Smith \& Townsend (1907), was placed in the genus Agrobacterium, a member of the family Rhizobiaceae, by Conn (1942) with other plant pathogenic and saprophytic species (Bergey's Manual, 1957).

Recently, numerical taxonomic studies (Graham, r964; Moffett \& Colwell, I968) and DNA hybridization experiments (Heberlein, De Ley \& Tijtgat, 1967) have demonstrated that, except for its pathogenicity, the crown-gall organism is indistinguishable from the saprophyte Agrobacterium radiobacter; both are also closely related to the fast-growing species of root-nodule bacteria of legumes (Rhizobium leguminosarum, $R$. trifolii, $R$. meliloti, $R$. phaseoli). The species $A$. rhizogenes and $A$. rubi show affinities with $A$. tumefaciens but A. pseudotsugae, A. gypsophilae and A. stellulatum do not (De Ley, Bernaerts, Rassel \& Guilmot, I966).

Kerr (1969) isolated crown-gall organisms which differed from typical Agrobacterium tumefaciens, and Keane et al. (1970) proposed that these organisms be designated $A$. radiobacter var. tumefaciens Biotype 2, typical crown-gall organisms being designated $A$. radiobacter var. tumefaciens Biotype I. Strains of $A$. rhizogenes showed similar properties to Biotype 2 crown-gall isolates and it was also proposed that $A$. rhizogenes be classified as a variety, A. radiobacter var. rhizogenes Biotype 2.

\footnotetext{
* Present address: Department of Microbiology, University of Birmingham, Birmingham, BI52TT.
} 
This study was undertaken to re-examine the taxonomy of crown-gall organisms by numerical analysis of nutritional characters, as applied to pseudomonads (Stanier, Palleroni \& Doudoroff, 1966; Sands, Schroth \& Hildebrand, 1970).

\section{METHODS}

Organisms. The organisms studied are shown, with their sources, in Table I. Tumourinducing ability was checked by inoculation into tomato plant internodes. Strains of rhizobia and Agrobacterium rhizogenes I855 were maintained on yeast extract, mannitol agar (YMA) (Nutman, 1946) using $0.4 \%$ Oxoid yeast extract (Oxoid Limited, London, S.E. I) in place of yeast water. The agrobacteria (excluding $A$. gypsophilae 1948) were maintained on sucrose, nutrient broth, yeast extract agar (SA) (Lippincott \& Lippincott, I965). Chromobacterium strains 10590 and I059I were also maintained on this medium. Other organisms were maintained on nutrient agar (NA). All experiments were performed at $25^{\circ} \mathrm{C}$.

Nutritional tests. Organisms were tested for their ability to use 6I compounds as sole carbon source, incorporated at a concentration of $0.1 \%(w / v)$ in the following medium (modified from Sundman, 1964) (g/900 ml distilled water): $\mathrm{NaNO}_{3}, 2.5 ; \mathrm{KH}_{2} \mathrm{PO}_{4}, \mathrm{I} \cdot \mathrm{O}$; $\mathrm{K}_{2} \mathrm{HPO}_{4}, 2 \cdot 0 ; \mathrm{MgSO}_{4} \cdot 7 \mathrm{H}_{2} \mathrm{O}, 0.3 ; \mathrm{CaCl}_{2}, 0 . \mathrm{I} ; \mathrm{NaCl}, 0.1 ; \mathrm{FeCl}_{3}, 0.0 \mathrm{I}$; Oxoid agar no, I ro; vitamin solutions $A, B$ and $C, 2.5 \mathrm{ml}$ of each. (Vitamin solutions: $A$-biotin, $20 \mu \mathrm{g}$; vitamin $\mathrm{B}_{12}, 40 \mu \mathrm{g}$; distilled water, $100 \mathrm{ml} ; B$-thiamine hydrochloride, $10 \mathrm{mg}$; nicotinic acid, $10 \mathrm{mg}$; calcium pantothenate, Io $\mathrm{mg}$; $p$-amino-benzoic acid, $10 \mathrm{mg}$; distilled water, $100 \mathrm{ml} ; C$-folic acid, $2.0 \mathrm{mg}$; $0.00 \mathrm{I} \mathrm{N}-\mathrm{NaOH}, \mathrm{IOO} \mathrm{ml}$ ). The vitamin solutions were autoclaved at $\mathrm{IO} \mathrm{lb} / \mathrm{in}^{2}$ for $10 \mathrm{~min}$ and stored at $4{ }^{\circ} \mathrm{C}$. The medium was dispensed in $90 \mathrm{ml}$ amounts and autoclaved at I $5 \mathrm{lb} / \mathrm{in}^{2}$ for $\mathrm{I} 5 \mathrm{~min}$. Carbon sources were prepared as I \% solutions and sterilized by filtration through Millipore (Millipore (U.K.) Ltd., Millipore House, Abbey Road, Park Royal, London NW I0 $7 \mathrm{SP})$ membrane filters $(0.22 \mu \mathrm{m}$ pore size) or by autoclaving; Io $\mathrm{ml}$ of carbon source solution was added to melted basal medium cooled to $50{ }^{\circ} \mathrm{C}$ and plates were poured ( $20 \mathrm{ml}$ per plate). The replica plating technique (Lederberg \& Lederberg, I952) proved unworkable with gummy colonies, consequently plates were inoculated with a zigzag streak using a wire loop. Minute inocula from young actively growing cultures ( 2 to 5 days) were used to minimize nutrient carry-over. After Io days of incubation carbon sources supporting visibly more growth than control plates without added carbon source were scored positive. A few dubious cases showing traces of growth were not scored. All tests were repeated at least twice.

The compounds tested were: glucose, sorbose, xylose, fructose, maltose, lactose, mannose, melezitose, melibiose, cellobiose, trehalose, raffinose, amygdalin, sucrose, galactose, arabinose, inulin, sorbitol, dulcitol, mannitol, erythritol, glycerol, adonitol, rhamnose, aesculin, dextrin, vanillin, mucic acid, sodium malonate, potassium sodium tartrate, sodium gluconate, glucuronic acid, sodium fumarate, sodium formate, tri-sodium citrate, sodium acetate, sodium benzoate, sodium lactate, sodium oxalate, sodium propionate, sodium succinate, sodium malate, sodium hippurate, sodium- $n$-butyrate, urea, biuret, betaine (neutralized), allantoin, ethanol, iso-propanol, ethylene glycol, leucine, lysine, arginine, histidine, cystine, asparagine, sodium glutamate, serine, glycine (D-isomers of sugars except for L-sorbose and L-rhamnose, L-isomers of amino acids).

Glucose utilization. Production of acid from the aerobic or anaerobic breakdown of glucose (Hugh \& Leifson, 1953) was examined using the medium of Baird-Parker (1963). Readings were made at intervals up to 2I days. Organisms showing marked acidification of both aerobic and anaerobic tubes were scored positive. Those producing no acid or acid only in the aerobic tube were scored negative. 
Table I. Strains used and their source

Species name and strain no.

Agrobacterium tumefaciens

B6

II BNV6

8 I 50

A6

A66B

T37

TUM6

TUM7

TUM8

TUMI 5

TUMI 7

IO39 $\mathrm{ng} \dagger$

I04 I

1058

\section{Source*}

J. A. Lippincott

J. A. Lippincott

N.C.I.B.

R. E. Beardsley

R. E. Beardsley

R. E. Beardsley

Ch. Bonnier

Ch. Bonnier

Ch. Bonnier

Ch. Bonnier

Ch. Bonnier

C.C.M.

C.C.M.

C.C.M.

Agrobacterium radiobacter var. tumefaciens

Biotype I

$\begin{array}{ll}\text { KI } 5 & \text { A. Kerr } \\ \text { KI9 } & \text { A. Kerr } \\ \text { K28 } & \text { A. Kerr }\end{array}$

Biotype 2
K34
A. Kerr

$\mathrm{K} 40$

K4I

A. Kerr

A. Kerr

Agrobacterium radiobacter

H29

F. Tanner

$\mathrm{M} 2 / \mathrm{I}$

L2/2/I

sioo5

J. De Ley

J. De Ley

Ch. Bonnier

Agrobacterium radiobacter var. radiobacter

Biotype I

к6

K9

Biotype 2

K84

A. Kerr

A. Kerr

A. Kerr

Agrobacterium rhizogenes

I 855

5

N.C.P.P.B.

N.C.P.P.B.

Agrobacterium rubi

H36

F. Tanner

Agrobacterium pseudotsugae I 80

Agrobacterium gypsophilae I 948

N.C.P.P.B.

Rhizobium meliloti

R2 I

2001

2003

2004

2005

2006

2009:

Rhizobium phaseoli

360 I

3602

3603

D. C. Jordan

R.C.R.

R.C.R.

R.C.R.

R.C.R.

R.C.R.

R.C.R.

R.C.R.

R.C.R.

R.C.R. 


\section{Table I (continued)}

Species name
and strain no.

\begin{tabular}{ll} 
and strain no. & \multicolumn{1}{c}{ Source* } \\
Rhizobium leguminosarum & \\
1002 & R.C.R. \\
1003 & R.C.R. \\
Rhizobium trifolii & \\
2 & R.C.R. \\
33 & R.C.R. \\
36 & R.C.R. \\
204 & R.C.R. \\
0403 & R.C.R. \\
0462 & R.C.R. \\
VANC & J. N. Reeve \\
Other rhizobia & \\
$3208 \S$ & R.C.R. \\
$3404 \$$ & R.C.R. \\
$3405 \S$ & R.C.R. \\
3807 & R.C.R. \\
Chromobacterium lividum & \\
NCTCI0590 & J. Taylor \\
NCTCI059I & J. Taylor \\
Xanthomonas campestris & \\
528 & N.C.P.P.B. \\
Xanthomonas hyacinthi & \\
599 & N.C.P.P.B. \\
Erwinia carotovora & \\
312 & N.C.P.P.B. \\
Pseudomonas savastanoi & \\
1006 & N.C.P.P.B. \\
I 506 & N.C.P.P.B. \\
Other soil and root nodule isolates \\
\end{tabular}

$\begin{array}{ll}\text { RB.3b } & \text { Runner bean nodule isolate } \\ \text { RB. Ib } & \text { Runner bean nodule isolate } \\ \text { RED CLOV } & \text { Departmental nodule isolate } \\ \text { VETCH } & \text { Departmental nodule isolate } \\ \text { E } & \text { Soil pseudomonad } \\ \text { Ps. Cogbil } & \text { Clinical pseudomonad isolate } \\ \text { Ps. Preen } & \text { Clinical pseudomonad isolate } \\ \text { Coral } & \text { Isolate from coral }\end{array}$

* Investigator or source supplying culture. J. A. Lippincott, Department of Biological Sciences, Northwestern University, Evanstown, Illinois 6020I, U.S.A.; N.C.I.B., National Collection of Industrial Bacteria, Torry Research Station, I35 Abbey Road, Aberdeen AB9 8DG, Scotland; R. E. Beardsley, Manhattan College, New York, U.S.A.; Ch. Bonnier, Chaire de Microbiologie, Faculté des Sciences Agronomiques de l'État, Gembloux, Belgium; C.C.M., Czechoslovak Collection of Micro-organisms, J. E. Purkyně University, Brno, třida Obránců miru, Io, Czechoslovakia; A. Kerr, Department of Plant Pathology, Waite Agricultural Research Institute, University of Adelaide, Glen Osmond, South Australia 5064; F. Tanner, International Centre for Information on and Distribution of Type Cultures, Institute of Hygiene and Bacteriology, 19 Av. César Roux, Lausanne, Switzerland; J. De Ley, Lab. voor Microbiologie en Microbiele Genetica, Faculteit der Wetenschappen, Rijksunwersiteit, Ghent, Belgium; N.C.P.P.B., National Collection of Plant Pathogenic Bacteria, Plant Pathology Laboratory, Ministry of Agriculture Fisheries and Food, Hatching Green, Harpenden, Herts, England; D. C. Jordan, Department of Microbiology, University of Guelph, Guelph, Ontario, Canada; R.C.R., Rothamsted Collection of Rhizobia, Department of Microbiology, Rothamsted Experimental Station, Harpenden, Herts, England; J. N. Reeve, Department of Microbiology, University of British Columbia, Vancouver 8, Canada; J. Taylor, Salmonella Reference Laboratory, Central Public Health Laboratories, Colindale Avenue, London NW 9, England.

$\dagger$ A clonal variant from the freeze-dried strain received which failed to produce copious amounts of gum on carbohydrate media.

¥ Two clones of this strain, differing in colonial morphology were used in this study. The clones were designated 2009 I and 2009 II but both gave identical results in the work reported here.

$\S$ 'Slow-growing' strains. 
Hydrolysis of starch, caesin and gelatin. YMA or NA was modified by the addition of either (i) an autoclaved 10 \% solution of soluble starch to give a final concentration of $1 \%$ or (ii) an autoclaved $10 \%$ solution of Oxoid skim milk to give a final concentration of $2 \%$, (iii) a $10 \%$ solution of gelatin, sterilized by steaming on three consecutive days, to give a final concentration of $0.4 \%$.

Plates were inoculated with streaks of organisms and incubated for up to 14 days. Casein hydrolysis was recorded by observing a clearing around the growth, starch and gelatin hydrolysis were observed by the application of Lugol's iodine and Frazier's reagent respectively (Cowan \& Steel, 1965).

Alkali from arginine anaerobically. Ability to utilize arginine under anaerobic conditions with the release of alkali was examined in the medium of Møller (I955) using 0.00 I \% bromothymol blue as the only indicator. Test medium contained I \% L-arginine and control medium contained none. Development of a blue coloration in the arginine medium, but not the control medium, within I4 days was scored positive.

3-Ketolactose. Ability to produce 3-ketolactose from lactose was examined by the method of Bernaerts \& De Ley (I963).

Numerical methods. All tests were scored qualitatively as positive, negative, or in a few cases unavailable or inapplicable. The data was punched on cards and analysed on the KDF 9 computer of the University of Birmingham using a computer program which:

(i) calculated and printed similarity coefficients between pairs of organisms. Two types of coefficients were calculated: simple matching (or S.M.) similarity coefficients (Sneath, 1962) in which both shared negative and positive results are regarded as similarities and simple matching coefficients ignoring negative matches or positive only (P.O.) similarity coefficients (Sneath, I957);

(ii) clustered the similarity coefficients by the pair-group average linkage method of Sokal \& Michener (1958).

The data from the 3-ketolactose test was excluded from the numerical analysis.

\section{RESULTS}

The results of the numerical analysis in dendrograms I and 2 (Fig. I, 2) show that the majority of fast-growing rhizobia and agrobacteria can be separated into four groups, defined by a posteriori weighting of certain characters, and completely unrelated to pathogenicity.

The major difference between the clustering of the S.M. coefficients and the P.o. coefficients is the unexpectedly wide separation of group IV in dendogram 2 from the other rhizobia and agrobacteria. This can be explained by the general inactivity of strains in this group; for example, Agrobacterium tumefaciens B6 gave 42/66 positive results whereas Rhizobium trifolii 2 gave $34 / 66$. Since not all of the 34 positives were also positive for B6, the number of shared positive matches was low.

The major groups formed are as follows:

Group I: 3-ketolactose + , erythritol - , lysine + , ornithine + , tartrate - , mucic acid - .

Strains not included in this group did not produce 3-ketolactose from lactose. Both tumourigenic and non-tumourigenic strains are present within the group but are not resolvable.

Group II: 3-ketolactose -, erythritol + (except Agrobacterium rubi H36), lysine +, ornithine + , tartrate - , mucic acid - .

This group is made up essentially of strains of Rhizobium meliloti but one strain of $R$. phaseoli, 3602, and $A$. rubi $\mathrm{H} 36$ are also included. 
Group III: 3-ketolactose - , erythritol +, lysine +, ornithine +, tartrate + , mucic acid + .

This group contains all the Biotype 2 strains of Keane et al. (1970) and as in Group I the pathogens are indistinguishable from the non-pathogen (K84). Rhizobium strain 3807 is also a member of this group as is Agrobacterium rhizogenes $\mathrm{I} 855$.

Group IV: 3-ketolactose -, erythritol +, lysine -, ornithine -, tartrate and mucic acid variable.

All named strains of Rhizobium leguminosarum, $R$. trifolii and $R$. phaseoli, except strains 0462 and 3602 , together with unnamed nodule isolates RB. Ib and RB. $3 \mathrm{~b}$ are included in this group. It is not possible to resolve the three named species of rhizobium within the group.

\section{Other groups}

The three strains of slow-growing rhizobia examined cluster together with Rhizobium trifolii 0462 . It is of interest that 0462 , a pink pigmented $\mathrm{S}_{2} \mathrm{P}_{11}$ phage mutant of $R$. trifolii 0403, grew slowly and utilized butyrate, as did the three slow-growing strains, but no strain in groups I-IV. Agrobacterium gypsophilae I948 is most similar to Erwinia carotovora 3I 2 and $A$.pseudotsugae 180 to the chromobacterial strains 10590 and I059I. The pseudomonads and xanthomonads do not form a distinct group.

\section{DISCUSSION}

Previous detailed numerical analyses of agrobacteria either failed to include Agrobacterium rhizogenes (Graham, I964) or failed to detect the differences between A.rhizogenes and $A$. tumefaciens (Moffett \& Colwell, 1968). However, the results presented here clearly indicate that $A$. rhizogenes (as represented by strain 1855) and the Biotype 2 strains of A. tumefaciens cluster separately from $A$. radiobacter, and A. tumefaciens. Agrobacterium rhizogenes 5 is a member of the tumefaciens/radiobacter cluster, and indeed De Ley et al. (I966) and Lippincott \& Lippincott (I969) report that this strain is a typical crown-gall-forming organism.

\section{Nomenclature of the groups}

There is an obviously close relationship between the organisms in groups I-IV and this is most evident in dendrogram I, where all the groups form a single cluster at over $75 \%$. The separation of group IV, when P.o. coefficients are analysed has been explained. On the basis of these results taken in conjunction with genetic evidence (Klein \& Klein, 1953; Kern, I965a, $b$, 1969) phage work (Roslycky, Allen \& McCoy, 1960, I962) serological crossreactions (Graham, I963, I97I; Vincent \& Humphrey, 1970; White, I971) and DNA hybridization (Heberlein et al. 1967) this author agrees with the proposal, first made by Graham (1964), that Agrobacterium and Rhizobium should be combined into a single genus Rhizobium and it is suggested that groups I-IV should be taken to represent four speciesgroups within this genus.

Group I: Rhizobium radiobacter. A species containing both saprophytic and tumourinducing organisms. Graham (1964) defined varieties within this species on the basis of pathogenicity, and at present varieties can only be distinguished by pathogenicity-testing. As observed by De Ley (I968), ability to form 3-ketolactose seems to be characteristic of this species and Keane et al. (I970) isolated 3-ketolactose-positive strains capable of producing hairy root disease.

Group II: Rhizobium meliloti. The true position of Agrobacterium rubi $\mathrm{H} 36$ is dubious since 


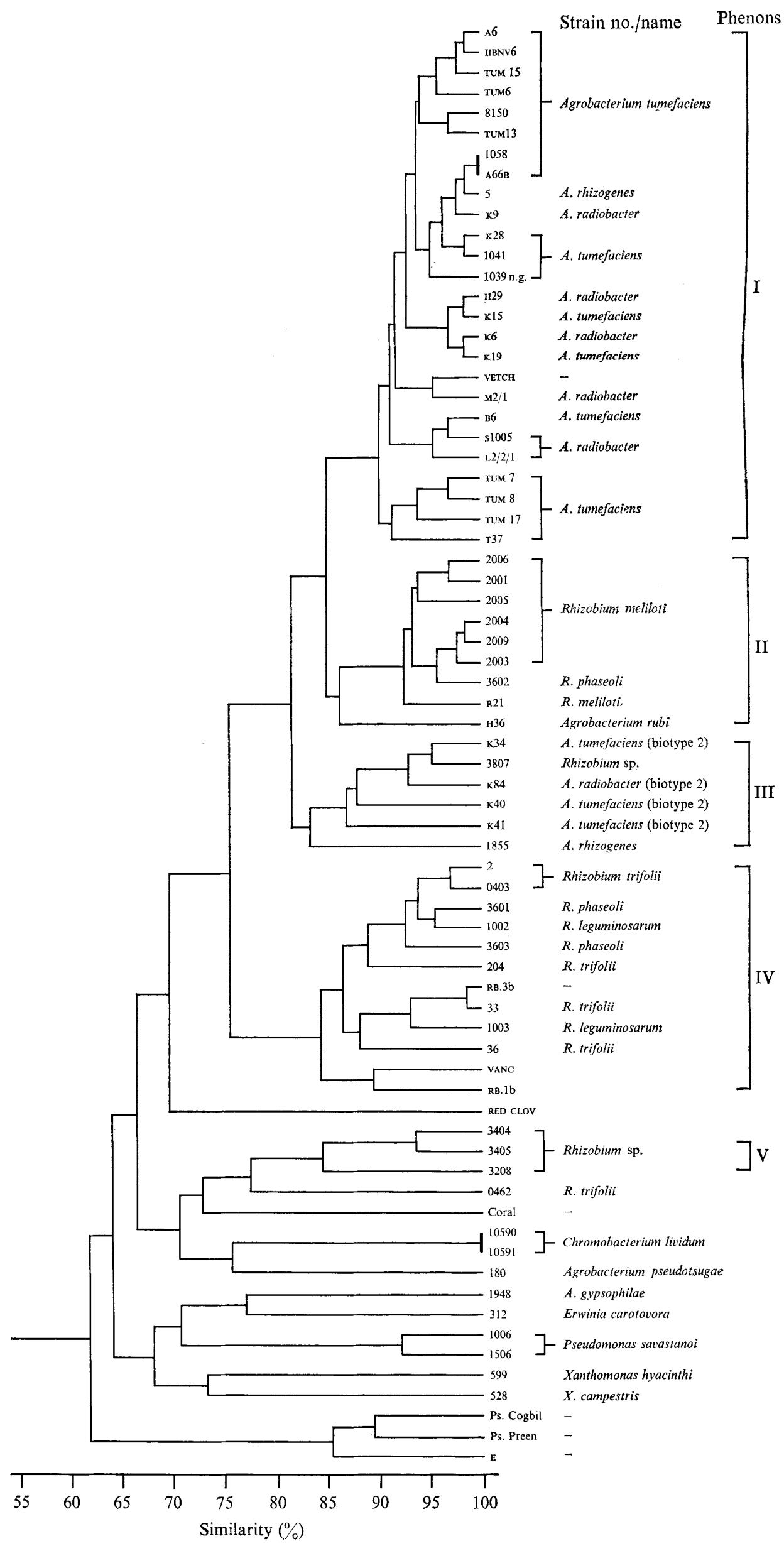

Fig. I. Dendrogram I produced as a result of clustering S.M. similarity coefficients by the pairgroup average linkage method (Sokal \& Michener, 1958). Organisms are designated by strain numbers (see Table I). 


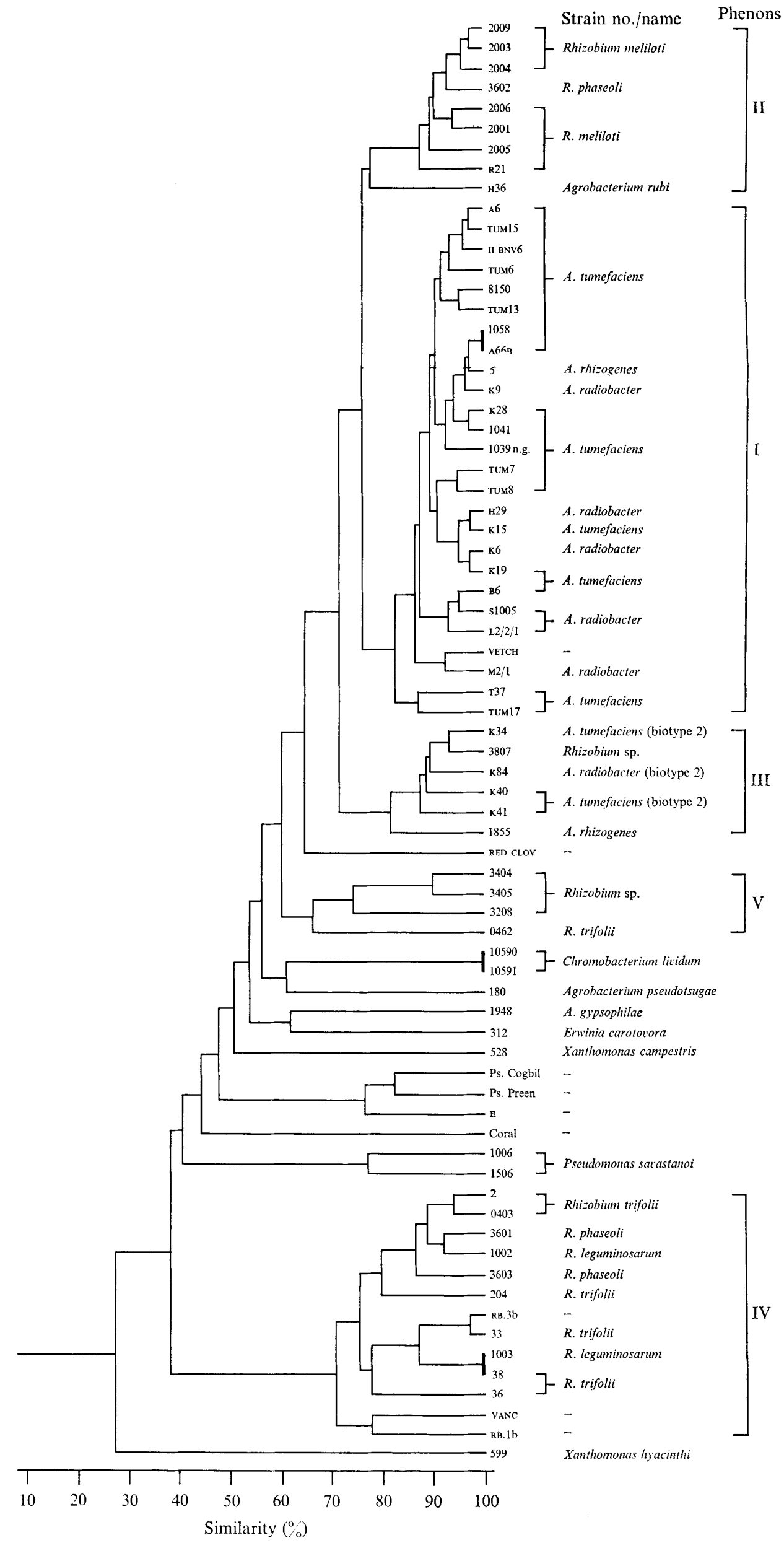

Fig. 2. Dendrogram 2 produced as a result of clustering P.o. similarity coefficients by the pairgroup average linkage method (Sokal \& Michener, 1958). Organisms are designated by strain numbers (see Table I). 
Table 2. Proposed nomenclature for pathogenic strains of Rhizobium

\begin{tabular}{|c|c|c|}
\hline Disease & $\begin{array}{l}\text { Proposed designation } \\
\text { (species group } I^{*} \text { ) }\end{array}$ & Old designations \\
\hline Non-pathogenic & Rhizobium radiobacter state, saprophytic & $\begin{array}{l}\text { Agrobacterium radiobacter } \\
\text { A. radiobacter var. radiobacter } \\
\text { Rhizobium radiobacter var. radiobacter } \\
\text { Agrobacterium radiobacter var. } \\
\text { radiobacter Biotype I }\end{array}$ \\
\hline Crown gall & Rhizobium radiobacter state, tumourigenic & $\begin{array}{l}\text { Agrobacterium tumefaciens } \\
\text { A. radiobacter var. tumefaciens } \\
\text { Rhizobium radiobacter var. } \\
\text { tumefaciens } \\
\text { Agrobacterium radiobacter var. } \\
\text { tumefaciens Biotype I }\end{array}$ \\
\hline Hairy root & Rhizobium radiobacter state, rhizogenic & $\begin{array}{l}\text { A. radiobacter var. rhizogenes } \\
\text { Biotype } \mathbf{I}\end{array}$ \\
\hline
\end{tabular}

* Strains of species Group III capable of producing the same disease would be designated by the same 'state' epithets.

it failed to cluster with this group when morphological and physiological characters were analysed (White, I97I). Moffett \& Colwell (1968) examined two strains designated $A$. rubi and their results showed that the two strains differed in several respects. The taxonomy of strains named $A$. rubi still needs clarification.

Group III. As with group I, crown-gall-forming organisms, the Biotype 2 strains of Keane et al. (1970), also occur in this group, but Group III is clearly separated from Group I by the Rhizobium meliloti cluster. Keane et al. (1970) demonstrated the close similarity between Agrobacterium rhizogenes and the Biotype 2 crown-gall isolates but failed to demonstrate the clear difference between typical crown-gall isolates and the Biotype 2 strains which is apparent here. Strain 1855 gives typical reactions of the species A. rhizogenes (White, I97I) and it may be that all group III strains should be incorporated into this species. However, since the type culture of $A$. rhizogenes was not included in this work it is suggested that no new epithet is applied until further studies have been made on organisms related to those in group III.

Group IV: Rhizobium leguminosarum. In line with the findings of Graham (1964) strains of $R$. leguminosarum, $R$. trifolii and $R$. phaseoli are included in this single enlarged species.

\section{The position of the other agrobacteria}

As remarked, Agrobacterium rubi is probably closely related to the groups described above but the exact relationship needs further elucidation. As regards the species A. gypsophilae it was suggested (De Ley, I968) on the basis of DNA base composition that the organism is probably related to Erwinia and the results presented here show that A. gypsophilae 1948 and $E$. carotovora 312 might well be considered as members of the same genus. There is no evidence to support the inclusion of $A$. gypsophilae in the genus Xanthomonas (Prévot, 196r). De Ley (1968) suggested that $A$. gypsophilae be re-named $E$. herbicola since both have yellow pigmentation. Both strains I948 and 3 I 2 strongly ferment glucose.

The results also confirm the suggestions of others that Agrobacterium pseudotsugae 180 is not closely related to the other agrobacteria. The apparent relationship with the chromobacteria demonstrated here is of interest since the DNA base composition of strain 180 is within the chromobacterial range (De Ley et al. 1966). However, a close phenetic relation- 
Table 3. Possible diagnostic characters for separating the four species of fast-growing Rhizobium recognized in this work

\begin{tabular}{|c|c|c|c|c|}
\hline Test & $\begin{array}{l}\text { Rhizobium } \\
\text { radiobacter }\end{array}$ & Group III & $\begin{array}{c}\text { Rhizobium } \\
\text { meliloti }\end{array}$ & $\begin{array}{c}\text { Rhizobium } \\
\text { leguminosarum }\end{array}$ \\
\hline 3-Ketolactose formation & + & o & 0 & 0 \\
\hline Litmus milk brown in 14 days & + & 0 & 0 & 0 \\
\hline Ethanol* & + & 0 & $\mp$ & o \\
\hline Erythritol* & o & + & + & + \\
\hline Ornithine* & + & + & + & o \\
\hline Lysine* & + & + & + & 0 \\
\hline Tartrate* & 0 & + & o & o \\
\hline Mucic acid* & 0 & + & 0 & \pm \\
\hline Melezitose* & + & 0 & + & o \\
\hline Growth on $2 \% \mathrm{NaCl}$ & + & 0 & + & 0 \\
\hline Growth at $37^{\circ} \mathrm{C}$ & + & 0 & + & 0 \\
\hline Growth at $40^{\circ} \mathrm{C}$ & $\mp$ & 0 & + & o \\
\hline Malonate* & 0 & \pm & $\mp$ & 0 \\
\hline Propionate* & + & $\overline{0}$ & $\mp$ & o \\
\hline Butyrate* & 0 & 0 & o & 0 \\
\hline \multicolumn{5}{|c|}{$\begin{array}{l}* \text { Utilization of. } \\
+ \text { All or most strains positive. } \\
\pm \text { More than half strains positive. } \\
\mp \text { Less than half strains positive. } \\
\text { o Few or no positive strains. }\end{array}$} \\
\hline
\end{tabular}

ship was not apparent in an analysis of other properties (White, 1971). The position of this organism must remain undecided.

\section{The slow-growing rhizobia}

Our results confirm that there is less similarity between the fast and slow-growing rhizobia than between the fast growing rhizobia and the agrobacteria. However, no suggestion can be made as to whether the slow growers should be placed in a new genus.

\section{Designation of pathogenic rhizobia}

Some members of both groups I and III are capable of producing crown-gall tumours and it would appear that group III strains can transfer the property to group I strains in vivo (Kerr, I97I). It thus appears that the property of pathogenicity has little or no taxonomic value and it is suggested that the varietal epithets suggested by Graham (1964) be reduced to the infra-subspecific rank 'state'. To do so removes the requirement to designate crowngall organisms in different species groups by different varietal epithets.

Thus strains in groups I and III may be found in one of at least three states (Table 2) and there is some evidence (MacGregor \& Alexander, I97I) that root nodulating rhizobia may also have a transitory tumourigenic state.

\section{Identification}

Using this scheme, crown-gall organisms could belong to one of at least two species. Table 3 gives a list of properties taken from the nutritional results analysed here and also from the results of White (1971) which should aid the identification of the four species of Rhizobium related to the tumour-inducing and root-proliferating pathogens.

I wish to acknowledge the financial assistance provided by the Science Research Council, and to thank Dr Phyllis Pease for her advice and help. 


\section{REFERENCES}

Baird-PARker, A. C. (1963). A classification of Micrococci and Staphlococci based on physiological and biochemical tests. Journal of General Microbiology 30, 409-427.

Bergey's Manual of Determinative Bacteriology (1957). 7 th edn. Edited by R. S. Breed, E. G. D. Murray \& N. Smith. London: Baillière, Tyndall \& Cox.

Bernaerts, M. J. \& De Ley, J. (I963). A biochemical test for crown gall bacteria. Nature, London I97, 406-407.

ConN, H. J. (1942). The validity of the genus Alcaligenes. Journal of Bacteriology 44, 353-360.

Cowan, S. T. \& Steel, K. J. (1965). Manual for the Identification of Medical Bacteria, pp. 139, I46. Cambridge: Cambridge University Press.

DE LEY, J. (I968). DNA base composition and hybridisation in the taxonomy of the phytopathogenic bacteria. Annual Review of Plant Pathology 6, 63-90.

De Ley, J., Bernaerts, M., Rassel, A. \& Guilmot, J. (1966). Approach to an improved taxonomy of the genus Agrobacterium. Journal of General Microbiology 43, 7-I 7.

Graham, P. H. (1963). Antigenic affinities of the root-nodule bacteria of legumes. Antonie van Leeuwenhoek 29, 28I-291.

Graham, P. H. (I964). Application of computer techniques to the taxonomy of root-nodule bacteria. Journal of General Microbiology 35, 5 I I-5I 7.

Graham, P. H. (1971). Serological studies with Agrobacterium radiobacter, A. tumefaciens and Rhizobium strains. Archiv für Mikrobiologie 78, 70-75.

Heberlein, G. T., DE Ley, J. \& Tutgat, R. (I967). Deoxyribonucleic acid homology and taxonomy of Agrobacterium, Rhizobium and Chromobacterium. Journal of Bacteriology 94, I I6-I 24.

Hugh, R. \& LeIfSON, E. (I953). The taxonomic significance of fermentative versus oxidative metabolism of carbohydrates by various gram-negative bacteria. Journal of Bacteriology 66, 24-26.

KeAne, P. J., KeRr, A. \& New, P. B. (1970). Crown gall of stone fruit. II. Identification and nomenclature of Agrobacterium isolates. Australian Journal of Biological Sciences 23, 585-595.

KERN, H. (1965a). Untersuchungen zur genetischen Transformation zwischen Agrobacterium tumefaciens und Rhizobium spec. I. Übertragung der Fähigkeit zur Induktion pflanzlicher Tumoren auf Rhizobium spec. Archiv für Mikrobiologie 51, I40-I 55.

KerN, H. (1965b). Untersuchungen zur genetischen Transformation zwischen Agrobacterium tumefaciens und Rhizobium spec. II. Vergleichende morphologische, physiologische und biochemische Untersuchungen an den Partnern einer Transformation. Archiv für Mikrobiologie 52, 206-223.

KerN, H. (I969). Interspezifische Transformationen zwischen Agrobacterium tumefaciens und Rhizobium leguminosarum. Archiv für Mikrobiologie 66, 63-68.

KERR, A. ( I 969). Crown gall of stone fruit. I. Isolation of Agrobacterium tumefaciens and related species. Australian Journal of Biological Sciences 22, I I I-I 6 .

KerR, A. (197I). Acquisition of virulence by non-pathogenic isolates of Agrobacterium radiobacter. Physiological Plant Pathology r, 241-246.

KLEIN, D. T. \& KLEIN, R. M. (I953). Transmittance of tumor-inducing ability to avirulent crown-gall and related bacteria. Journal of Bacteriology 66, 220-228.

Lederberg, J. \& Lederberg, E. M. (I952). Replica plating and indirect selection of bacterial mutants. Journal of Bacteriology 63, 399-406.

LippincotT, J. A. \& LippincotT, B. B. (1965). Timing of events in crown-gall tumor development on Pinto bean leaves. Developmental Biology I2, 309-327.

Lippincotr, J. A. \& LippincotT, B. B. (1969). Tumour-initiating ability and nutrition in the genus Agrobacterium. Journal of General Microbiology 59, 57-75.

Macgregor, A. N. \& Alexander, M. (I97I). Formation of tumor-like structures on legume roots by Rhizobium. Journal of Bacteriology r05, 728-732.

Moffett, M. L. \& Colwell, R. R. (1968). Adansonian analysis of the Rhizobiaceae. Journal of General Microbiology 5I, 245-266.

Møller, V. (1955). Simplified tests for some amino acid decarboxylases and for the arginine dihydrolase system. Acta pathologica et microbiologica scandinavica $36,158-172$.

Nutman, P. S. (1946). Variation within strains of clover nodule bacteria in the size of nodule produced and in the 'effectivity' of the symbiosis. Journal of Bacteriology 5I, 4I I-432.

PrÉvot, A. R. (196I). Traité de systématique bactérienne. Paris: Dunod. 
Roslycky, E. B., Allen, O. N. \& McCoy, E. (1960). Certain properties of bacteriophages of Agrobacterium radiobacter. Bacteriological Proceedings, p. 28.

Roslycky, E. B., Allen, O. N. \& MCCoy, F. (1962). Phages for Agrobacterium radiobacter with reference to host range. Canadian Journal of Microbiology $8,7 \mathrm{I}-78$.

SANDS, D. C., SCHRoth, M. N. \& Hildebrand, D. C. (1970). Taxonomy of phytopathogenic Pseudomonads. Journal of Bacteriology ror, 9-23.

SMITH, E. F. \& TownSEND, C. O. (1907). A plant tumour of bacterial origin. Science, New York 25, 67I-673.

SNEATH, P. H. A. (1957). Application of computers to taxonomy. Journal of General Microbiology 17, $201-226$.

SNEATH, P. H. A. (1962). The construction of taxonomic groups. Symposia of the Society for General Microbiology 12, 289-396.

SoKAL, R. R. \& Michener, C. D. (1958). A statistical method for evaluating systematic relationships. University of Kansas Science Bulletin 38, $1409-1438$.

Stanier, R. Y., Palleroni, N. J. \& Doudoroff, M. (1966). The aerobic pseudomonads: a taxonomic study. Journal of General Microbiology 43, I59-27I.

SunDMAN, V. (1964). A description of some lignanolytic soil bacteria and their ability to oxidize simple phenolic compounds. Journal of General Microbiology 36, 171-183.

VinCENT, J. M. \& HuMPHREY, B. (1970). Taxonomically significant group antigens in Rhizobium. Journal of General Microbiology 63, 379-382.

WHITE, L. O. (197I). The taxonomy of Agrobacterium tumefaciens. Ph.D. Thesis, University of Birmingham. 